\title{
KEANEKARAGAMAN SPESIES KELAS GASTROPODA PADA HUTAN MANGROVE PANTAI BAMA TAMAN NASIONAL BALURAN
}

\author{
Hendri Budiawan, Fuad Ardiansyah, Fitri Nurmasari \\ Program Studi Biologi, Fakultas Matematika dan Ilmu Pengetahuan Alam \\ Universitas PGRI Banyuwangi \\ Email: hendribudiawan94@gmail.com
}

\begin{abstract}
ABSTRAK
Kawasan Mangrove Pantai Bama adalah salah satu kawasan yang menjadi area konservasi Taman Nasional Baluran. Terbatasnya informasi mengenai Keanekaragaman Gastropoda di Hutan Mangrove Pantai Bama Taman Nasional Baluran tepatnya di area mangrove Kelor-Manting hal ini yang mendorong peneliti ingin melakukan studi pendahuluan untuk mengetahui tingkat keanekaragaman Gastropoda di daerah tersebut. Tujuan dalam penelitian ini yaitu untuk mengetahui keanekaragaman dan dominansi Gastropoda yang ada di Hutan Mangrove Pantai Bama Taman Nasional Baluran. Penelitian dilakukan pada tanggal 10 Maret-9 April 2020. Metode yang digunakan pada penelitian ini yaitu dengan menggunakan metode purposive sampling. Pengambilan sampel dibagi menjadi 3 stasiun dengan jarak tiap stasiun $200 \mathrm{~m}$ dan dengan luas tiap stasiun $450 \mathrm{~m}^{2}$. Setiap stasiun dibagi menjadi 3 garis transek jarak tiap garis transek $30 \mathrm{~m}$, dalam satu garis transek terdapat 10 plot berukutan $2 \times 2$ $\mathrm{m}^{2}$. Berdasarkan pengamatan di 3 stasiun diperoleh Gastropoda 16 famili dengan 20 genus dan 21 spesies. Keanekaragaman $\left(\mathrm{H}^{\prime}\right)$ Gastropoda pada tiap stasiun 2.7589-2.8384 yang menunjukkan bahwa kawasan ini memiliki nilai keanekaragaman sedang. Dominansi (C) gastropoda pada setiap stasiun 0.0653-0.0743 yang menunjukkan bahwa kawasan ini memiliki nilai indeks Dominansi rendah.
\end{abstract}

Kata kunci : Keanekaragaman, Dominansi, Gastropoda, Mangrove

\begin{abstract}
Abstrak
Bivalves (shellfish) are biota that usually live in the substrate of the bottom waters. Bivalves have important values in the marine water ecosystem. Ecologically, Bivalvia is categorized as an important biota that makes up an ecosystem because it is a filter fideer so that it is able to filter organic matter in the waters. Sampling is divided into 3 stations with a distance of $200 \mathrm{~m}$ each and with an area of each station $450 \mathrm{~m} 2$. Each station is divided into 3 transect lines, the distance of each transect line is $30 \mathrm{~m}$, in one transect line there are 10 sequential plots of $2 \times 2 \mathrm{~m} 2$. From the research results obtained 8 Family 9 Genus and 9 species, including: Family Arcidae, Mactridae, Mytilidae , Veneroidae, Placunidae, Ostreidae, Tellinidae and Pinnidae. The 9 genera found included: Anadara, Barbatia, Spisula, Modiolus, Periglypta, Placuna, Saccostrea, Tellina and Pinna, while 9 species found were: Anadara granosa, Barbatia Barbata, Spisula solida, Modiolus barbatus, Periglypta poerpera, Placuna Placenta, Saccostrea cucullata, Tellina timorensis, Pinna Nobilis. The total total of Mangrove Bivalves obtained was 628 individuals, the diversity index in all stations had an average of $H^{\prime}=1.66$ in the medium category, while the dominance index at all stations had an average of $C=$ 0.22. Then the dominance index is categorized as low.
\end{abstract}

Key to Determination: Bivalves, Diversity, Dominance, Bivalves, Temperature and $p H$

Keanekaragaman Spesies Kelas Gastropoda Pada Hutan Mangrove Pantai Bama Taman Nasional Baluran 


\section{PENDAHULUAN}

Kawasan konservasi Taman Nasional Baluran termasuk juga dalam Zona intertidal dan salah satu kawasan yang dikelolah oleh pihak pengelola Taman Nasional Baluran yang memiliki kawasan intertidal yang dapat dilakukan pengamatan langsung sebagai laboratorium alam, salah satunya Gastropoda yang ada di Pantai Bama. Pantai Bama memiliki ekosistem seperti ekosistem padang lamun, ekosistem terumbu karang, dan ekosistem mangrove. Dari ketiga ekosistem tersebut seperti yang terdapat pada hutan mangrove, berperan fungsi sebagai rumah habitat organisme yang menempati wilayah tesebut. Secara ekologis hutan hangrove memiliki peran fungsi sebagai pelindung pantai dari serangan angin, arus dan ombak dari laut, tempat mencari makan (feeding ground) tempat asuhan pembesaran (nursery ground) dan tempat pemijahan (Spauning ground) bagi biota perairan. Salah satu organisme yang mendiami dan melakukan aktivitas di hutan mangrove adalah Gastropoda. Katawinata et al. (1979) menyatakan bahwa Gastropoda berasosiasi dengan ekosistem mangrove sebagai tempat hidup, tempat berlidung, memijah dan juga sebagai suplai makanan. Gastropoda pada hutan di temukan di bagian daun, batang, ranting, menempel pada akar dan lantai hutan mangrove. Secara ekologis Gastropoda pada hutan mangrove bersifat tropik level II dan III. Pada tropik level II, Gastropoda sebagai konsumen tingkat 1 sedangkan pada tropik level III, Gastropoda sebagai konsumen tingkat 2 (Ardiyansyah, 2018).

Pada hutan mangrove Gastropoda dikelompokkan menjadi kelompok pendatang dan juga kelompok penghuni asli hutan mangrove. Bangen (2004) menjelaskan untuk kelompok Gastropoda pengunjung, sifatnya hanya sebagian dari siklus hidupnya. Artinya Gastropoda kelompok pengunjung hanya waktu tertentu berada pada hutan mangrove kemudian akan berpindah pada habitat lain. Sedangkan pada kelompok Gastropoda asli dalam hal ini Famili Potamididae, siklus hidupnya akan menghabiskan waktu berada di hutan mangrove.

Saat ini pada di Taman Nasional Baluran utamanya pada hutan mangrove 
yang terletak di pantai Bama, pernah dilakukan monitoring keberadaan moluska utamanya untuk kelas Gastropoda oleh Taman Nasional Baluran pada tahun 2005 dan ditemukan 17 spesies. Siwi (2017) juga pernah melakukan penelitian Gastropoda mangrove di sekitar pantai Si Runtoh dan ditemukan Gastropoda sebanyak 19 spesies. Akan tetapi penelitian Gastropoda di hutan mangrove Pantai Bama Taman Nasional Baluran pada area Kelor-Manting sampai saat ini,masih belum pernah di lakukan penelitian utamanya tentang keanekaragaman pesies Gastropoda disana.

\section{METODOLOGI PENELITIAN}

\subsection{Waktu dan TempatPenelitian}

Penelitian ini di laksanakan pada bulan Maret-April 2020 di Hutan Mangrove Pantai Bama Taman Nasional Baluran Kecamatan Banyuputih Kabupaten Situbondo Provinsi Jawa Timur, pengidentifikasian spesimen Gastropoda dilakukan di Laboratorium Biologi Fakultas MIPA Universitas PGRI Banyuwangi.

\subsection{Alat dan Bahan}

Alat yang digunakan dalam pengambilan data Gastropoda adalah Meteran (untuk pengukuran plot satu ke plot yang lain), Talirafia (untuk mengukur jarak stasiun ke stasiun lainnya), Kerangka kuadrat ukuran $2 \times 2 \mathrm{~m}^{2}$ (plot), Buku catatan dan alat tulis (untuk mencatat hasil spesimen yang didapat dan data yang lainnya), kamera (alat untuk dokumentasi), plastik klip (untuk wadah Gastropoda), $\mathrm{pH}$ tanah (untuk mengukur kadar $\mathrm{pH}$ tanah), bahan yang digunakan adalah spesimen Gastropoda dan alkohol

\subsection{ProsedurPenelitian}

\section{a. Penentuan Stasiun}

Pada penelitian ini di tetapkan 3 stasiun dengan 3 titik pengambilan sampel yaitu: 1).Stasiun 1 depan pos penjagaan pantai bama, Stasiun 2 terletak di kelor, Stasiun 3 terletak di manting. 


\section{b. Pengambilan Sampel}

Pada tiap pengambilan sampel Gastropoda dibagi menjadi 3 stasiun, dengan luas tiap setasiun berukuran $15 \mathrm{~m} \times 30 \mathrm{~m}$ sehingga didapatkan luas $450 \mathrm{~m}^{2}$. Pada tiap stasiun dibagi 3 garis transek, dengan panjang transek $30 \mathrm{~m}$ dan jarak antara transek satu dengan transek lainnya berjarak5 m. Dalam satu garis transek terdapat 10 kotak plot dengan ukuran $2 \times 2 \mathrm{~m}$,sehingga didapatkan luas kotak plot $4 \mathrm{~m}^{2}$ dengan jarak setiap kotak plot satudengan yang lainnya adalah $1 \mathrm{~m}$. Titik awal garis transek ditentukan dengan menggunakan GPS (Global Positioning System) yang dibentangkan tegak lurus terhadap garis pantai mulai dari vegetasi terluar ke arah daratan sampai batas akhir vegetasi mangrove.

\section{c. Identifikasi Morfologi Gastropoda mangrove}

Morfologi Gastropoda mangrove memiliki ciri-ciri bentuk cangkang, dan panjang lebar cangkang yang berbeda-beda. Untuk mengetahui jenis dan nama Spesies Gastropoda mangrove yang ditemukan maka perlu dilakukan identifikasi dengan cara penentuan morfologi variasi cangkang gastropoda berdasarkan jurnal penelitian terdahulu tentang gastropoda mangrove di Indonesia dan untuk penentuan ke tingkat spesies dilakukan pencocokan mulai body whorl, operculum, apex, spire, dan juga warna melalui web http://gastropods.com

\subsection{Analisis Data}

Data yang diperoleh dianalisis secara deskriptif kuantitatif yang meliputi, indeks indeks keanekaragaman dan dominansi kelas Gastropoda di Hutan Mangrove Pantai Taman Nasional Baluran.

\subsubsection{Indeks Keanekaragaman ( $\left.H^{\prime}\right)$}

Keanekaragaman disebut juga dengan kehetrogenan jenis. keanekaragaman menunjukkan adanya kekayaan spesies dalam komunitas dan keseimbangan dalam pembagian jumlah perindividu menghitung indeks ini adalah persamaaan ShannonWienner (Brower et al. 1990). 


$$
\mathrm{H}^{\prime}=-\sum\left(\frac{n i}{N}\right) \ln \left(\frac{n i}{N}\right)
$$

Keterangan:

$\mathrm{H}^{\prime} \quad=$ indeks keanekaragaman Shannon-wienner

$\mathrm{Ni} \quad=$ nilai penting dari setiap species (jumlah individu tiap jenis)

$\mathrm{N}=$ total nilai penting (jumlah total semua individu).

Kriteria penilaian indeks keanekaragaman shanon-Wiener dikelompokkan dalam 3 kriteria penilaian sebagai berikut:

$$
\begin{array}{ll}
\mathrm{H}^{\prime}<1 & : \text { Keanekaragaman rendah } \\
1<\mathrm{H}^{\prime}<3 & : \text { Keanekaragaman sedang } \\
\mathrm{H}^{\prime}>3 & : \text { Keanekargaman tinggi }
\end{array}
$$

\subsubsection{Indeks Dominasi Simpson $(C)$}

Indeks dominansi untuk menunjukkan adanya jenis biota tertentu yang mendominansi di perairan. Dominansi biota tertentu ini diketahui dengan indeks dominansi Simpson, yaitu menggunakan rumus sebagai berikut (Odum, 1971) yaitu :

$$
\mathrm{C}=\sum_{i=1}^{S}\left(\frac{n i}{N}\right)^{2}
$$

Keterangan :

$\mathrm{C}=$ indeks Dominansi Simpson

$\mathrm{ni}=$ jumlah individu jenis ke-i

$\mathrm{N}=$ jumlah total individu

$\mathrm{S}=$ jumlah spesies

Kriteria penilaian Indeks Dominansi Simson berkisar antara 1 - 0 dengan di kelompokkan dalam 3 rentang nilai kritria yaitu:

$0<\mathrm{C} \leq 0.30$ : Dominansi rendah

$0.30<\mathrm{C} \leq 0.60$ : Dominansi sedang

$0.60<\mathrm{C} \leq 1 \quad$ : Dominansi tinggi 


\section{HASIL DAN PEMBAHASAN}

\subsection{Hasil Data}

Tabel 3.1 Keanekaragaman ( $\mathrm{H}^{\prime}$ ) Gastropoda Mangrove Pantai Bama

\begin{tabular}{llccc}
\hline \multirow{2}{*}{ No } & Spesies & \multicolumn{3}{c}{ Keanekaragaman $(\mathbf{H})$} \\
\cline { 3 - 5 } & & $\mathbf{S 1}$ & $\mathbf{S 2}$ & $\mathbf{S 3}$ \\
\hline 1 & Notocypraea angustata & 0.0495 & 0.0098 & 0.0000 \\
\hline 2 & Vasum turbinellus & 0.0676 & 0.0656 & 0.0538 \\
\hline 3 & Nassarius melanoides & 0.2208 & 0.1408 & 0.1484 \\
\hline 4 & Cerithidea quoyii & 0.1115 & 0.1638 & 0.1952 \\
\hline 5 & Cerithidea cingulata & 0.2193 & 0.1552 & 0.1053 \\
\hline 6 & Telescopium telescopium & 0.1715 & 0.2516 & 0.2885 \\
\hline 7 & Cassidula aurifelis & 0.1695 & 0.1111 & 0.2369 \\
\hline 8 & Faunus ater & 0.1925 & 0.0770 & 0.0919 \\
\hline 9 & Lambis lambis & 0.0029 & 0.0000 & 0.0000 \\
\hline 10 & Chicoreus capucinus & 0.0402 & 0.1400 & 0.0554 \\
\hline 11 & Pugilina choclidium & 0.0899 & 0.1209 & 0.1417 \\
\hline 12 & Nerita lineata & 0.0977 & 0.1747 & 0.1813 \\
\hline 13 & Vexillum daedalum & 0.1285 & 0.1623 & 0.1690 \\
\hline 14 & Laevistrombus canarium & 0.1168 & 0.1165 & 0.1145 \\
\hline 15 & Polinices tumidus & 0.1115 & 0.0425 & 0.0760 \\
\hline 16 & Spaerassiminea miniata & 0.2000 & 0.1431 & 0.1122 \\
\hline 17 & Trochus niloticus & 0.1357 & 0.1492 & 0.1397 \\
\hline 18 & Conomurex luhuanus & 0.1508 & 0.1720 & 0.1122 \\
\hline 19 & Littorina saxatilis & 0.1515 & 0.2162 & 0.1723 \\
\hline 20 & Euchelus atratus & 0.2412 & 0.1344 & 0.1620 \\
\hline 21 & Littorina scabra & 0.1695 & 0.2567 & 0.2025 \\
\hline & Jumlah $\mathbf{H}^{\prime}$ & 2.8384 & 2.8033 & 2.7589 \\
\hline & Rata-rata $\mathbf{H}^{\prime}$ & & 2.8002 & \\
\hline
\end{tabular}

Keterangan: $\mathrm{H}^{\prime}=$ indeks keanekaragaman, $\mathrm{S} 1-3=$ Stasiun 1-3

Berdasarkan Tabel 3.1 dapat di ketahui nilai Keanekaragaman Gastropoda

Mangrove pada Pantai Bama Taman Nasional Baluran pada stasiun 1 nilai indeks keanekaragaman $\quad \mathrm{H}^{\prime}=2.8384$ menunjukkan bahwa nilai tersebut tingkat keanekaragaman sedang. Pada stasiun 2 menunjukkan nilai indeks keanekaragaman $\mathrm{H}^{\prime}=2.8033$ yang menunjukkan bahwa nilai keanekaragaman pada stasiun 2 menunjukkan sedangkan. pada stasiun 3 menujukakan nilai indeks keanekaragaman $\mathrm{H}^{\prime}=2.7589$ yang mengartikan bahwa pada stasiun 3 juga memiliki nilai 
keanekaragama sedang.

Tabel 3.2 Indeks Dominansi Gastropoda Mangrove Pantai Bama

\begin{tabular}{llccc}
\hline \multirow{2}{*}{ No } & \multirow{2}{*}{ Spesies } & \multicolumn{3}{c}{ Indeks Dominansi (C) } \\
\cline { 3 - 5 } & Sotocypraea angustata & S2 & S3 \\
\hline 1 & 0.0001 & 0.0000 & 0.0000 \\
\hline 2 & Vasum turbinellus & 0.0003 & 0.0003 & 0.0001 \\
\hline 3 & Nassarius melanoides & 0.0086 & 0.0021 & 0.0024 \\
\hline 4 & Cerithidea quoyii & 0.0011 & 0.0033 & 0.0057 \\
\hline 5 & Cerithidea cingulata & 0.0084 & 0.0028 & 0.0009 \\
\hline 6 & Telescopium telescopium & 0.0038 & 0.0138 & 0.0239 \\
\hline 7 & Cassidula aurifelis & 0.0036 & 0.0010 & 0.0111 \\
\hline 8 & Faunus ater & 0.0055 & 0.0004 & 0.0006 \\
\hline 9 & Lambis lambis & 0.0000 & 0.0000 & 0.0000 \\
\hline 10 & Chicoreus capucinus & 0.0001 & 0.0020 & 0.0002 \\
\hline 11 & Pugilina choclidium & 0.0006 & 0.0013 & 0.0021 \\
\hline 12 & Nerita lineata & 0.0007 & 0.0040 & 0.0045 \\
\hline 13 & Vexillum daedalum & 0.0016 & 0.0032 & 0.0036 \\
\hline 14 & Laevistrombus canarium & 0.0012 & 0.0012 & 0.0011 \\
\hline 15 & Polinices tumidus & 0.0011 & 0.0001 & 0.0004 \\
\hline 16 & Spaerassiminea miniata & 0.0062 & 0.0022 & 0.0011 \\
\hline 17 & Trochus niloticus & 0.0019 & 0.0025 & 0.0020 \\
\hline 18 & Conomurex luhuanus & 0.0025 & 0.0038 & 0.0011 \\
\hline 19 & Littorina saxatilis & 0.0026 & 0.0080 & 0.0038 \\
\hline 20 & Euchelus atratus & 0.0118 & 0.0018 & 0.0032 \\
\hline 21 & Littorina scabra & 0.0036 & 0.0149 & 0.0064 \\
\hline & Jumlah C & 0.0653 & 0.0687 & 0.0743 \\
\hline & Rata- rata C & & 0.0694 & \\
\hline
\end{tabular}

Keterangan: $\mathrm{C}=$ indeks dominansi, $\mathrm{S} 1-3=$ Stasiun 1-3

Berdasarkan Pada Tabel 3.2 Indeks dominansi Gastropoda Mangrove Pantai Bama Taman Nasional Baluran pada Stasiun 1 menunjukkan Indeks Dominansi $\mathrm{C}=0.0653$ yang di artikan bahwa nilai Indeks Dominansi pada stasiun 1 rendah. Pada stasiun 2 Indeks Dominansi $\mathrm{C}=0.0687$ yang di artikan bahwa nilai Indeks Dominansi pada stasiun 2 di katagorikan rendah. pada Stasiun 3 menunjukkan Indeks Dominansi $\mathrm{C}=0.567$ diartikan bahwa nilai Indeks Dominansi pada stasiun 3 di katagorikan rendah. 
Tabel 3.3 Faktor lingkungan Gastropoda Mangrove Pantai Bama

\begin{tabular}{clccccc}
\hline No & Parameter & Satuan & $\begin{array}{c}\text { Alat yang di } \\
\text { gunakan }\end{array}$ & Stasiun1 & Stasiun 2 & $\begin{array}{c}\text { Stasiun } \\
\mathbf{3}\end{array}$ \\
\hline 1 & Suhu & ${ }^{\circ} \mathrm{C}$ & $\begin{array}{c}\text { Thermometer } \\
\text { batang }\end{array}$ & 3.0 & 3.2 & 3.4 \\
\hline 2 & $\begin{array}{l}\text { Derajat } \\
\text { keasaman } \\
\text { air }\end{array}$ & $\mathrm{pH}$ & $\mathrm{pH}$ Air & 7.7 & 7.8 & 7.9 \\
\hline $\begin{array}{l}\text { Derajat } \\
\text { keasaman } \\
\text { tanah }\end{array}$ & $\mathrm{pH}$ & pH Tanah & 6.5 & 5.5 & 5.7 \\
\hline
\end{tabular}

Berdasarkan Tabel 3.3 Faktor lingkungan Gastropoda Mangrove di ketahui untuk parameter suhu di Stasiun 1-3 berkisar antara 30-34 ${ }^{\circ} \mathrm{C}$, Stasiun $232{ }^{\circ} \mathrm{C}$, Stasiun $334^{\circ} \mathrm{C}$ pada parameter $\mathrm{pH}$ Air di Stasiun 1 7.7, Stasiun 2 7.8, Stasiun 3 7.9, sedangkan pada parameter $\mathrm{pH}$ tanah di Stasiun 1 6.6, Stasiun 2 5.5, Stasiun 3 5.7

a. Indeks Keanekargaman

Keanekaragaman merupakan sebuah parameter biologi pada suatu komunitas yang kemudian dapat ditentukan kekayaan jenis keanekaragamannya. Budiman (1991) menjelaskan cara yang paling sederhana dalam mengukur suatu keanekaragaman jenis adalah dengan menghitung jumlah jenis atau spesies. Dari hasil analisis data penghitungan jenis spesies yang telah dilakukan penelitian di Hutan Mangrove Pantai Bama Taman Nasional Baluran maka didapatkan nilai indeks keanekaragaman Gastropoda $\left(\mathrm{H}^{\prime}\right)=2.7589-2.8384$ dengan katagori sedang di ketiga stasiun. Brower (1990) menjelaskan bahwa nilai indeks keanekragaman dikatagorikan menjadi tiga, yaitu jika nilai $\mathrm{H}^{\prime}=<1$ maka nilai indeks keanekaragman dikatagorikan menjadi rendah. Jika nilai indek keanekaragaman menunjukkan nilai $1<\mathrm{H}^{\prime}<3$ maka dikatagorikan sebagai keanekaragaman sedang dan jika nilai indeks keanekaragaman menunjukkan nilai $\mathrm{H}^{\prime}=>3$, maka nilai indeks keaekaragaman dikatagorikan tinggi.Penyebab tingginya nilai indeks keanekaragan Gastropoda dipengaruhi oleh beberapa faktor seperti yang dijelaskan oleh Arbi (2012) salah satunya tinggi atau 
rendah nilai indeks keanekaragaman dapat dipengaruhi oleh jumlah spesies yang didapatkan. Keanekaragaman mencakup beberapa beberapa hal pokok yaitu banyaknya jenis yang ada pada suatu konunitas dan kelimpahan dari masing-masing yang ada. Sehingga semakin kecil jumlah jenis dan variasi jumlah individu tiap jenis atau dan beberapa individu yang jumlahnya jauh lebih besar maka keanekaragaman akan mengecil. Kebs (1985) menambahkan suatu keanekaragaman jenis cederung akan rendah di dalam sebuah komunitas yang terkendali secara fisik maupun biologis serta pada ekosistem yang mengalami gangguan.

Keanekaragaman jenis Gastropoda sangat peting dalam menentukan batas kerusakan yang dilakukan manusia terhadap ekosistem mangrove sehigga kenekaragaman tersebut dapat mejadi bioindikator lingkungan pada hutan mangrove Pantai Bama Taman Nasional Baluran. Kustanti (2011), menyatakan bahwa jumlah spesies dalam sebuah komunitas sangatlah penting dari segi ekologi karena keanekaragaman jenis Gastropoda bertambah bila komunitas menjadi stabil. Ganguan terhadap biota menyebabkan penurunan yang nyata dalam keanekaragaman serta mempengaruhi ekosistem hutan mangrove secara langsung. Pada hasil penelitian jumlah indeks keanekaragaman Gastropoda yang di dapatkan pada stasiun 1 - 3 pada Pantai Bama Taman Nasional Baluran menunjukan rata-rata $\mathrm{H}^{\prime}=2.8002$ yang menunjukkan keanekargaman sedang. Hal tersebut sepakat dengan pernyataan Kustanti (2011) jika keanekaragaman Gastropoda mangrove pada Pantai Bama Taman Nasional Baluran menjadi sedang dikarenakan sedikit mengalami gangguan terhadap biota lain sehingga Gastropoda tidak mengalami penurunan jumlah spesies. Hal inilah yang menjadikan mengapa keanekargaman Gastropoda pada Pantai Bama Taman Nasional Baluran menjadi sedang.

b. Indeks Dominansi

Bedasarkan analisis data nilai indeks dominansi yang di ketahui dari hasil penelitian yang di lakukan pada hutan Mangrove Pantai Bama Taman Nasional Baluran maka di dapatkan nilai indeks keanekaragaman Gastropoda $(C)=0.0653$ - 
0.0743 dengan katagori rendah di dalam 3 stasiun. Odum (1971) menjelaskan bahwa nilai indeks dominansi di katagorikan menjadi tiga, yaitu jika nilai $\mathrm{C}=0<\mathrm{C} \leq 0.30$ maka nilai indeks dominansi di katagorikan rendah. Jika nilai indeks dominansi menunjukkan nilai $\mathrm{C}=0.30<\mathrm{C} \leq 0.60$ maka di katagorikan sebagai indeks dominansi sedang dan jika nilai indeks dominansi menunjukkan nilai $\mathrm{C}=0.60<\mathrm{C} \leq 1$ maka nilai indeks dominansi di katagorikan tinggi. Berdasarkan pada kriteria indek dominansi jika 0-0.30 maka tidak ada spesies yang mendominasi, jika 0.30 - 1 maka terdapat spesies tertentu yang mendominasi. Odum (1971) menambahkan apabila kisaran indeks kurang dari 1 maka dominansi dalam komunitas tersebut rendah dan menunjukkan struktur komunitas dalam keadaan stabil. Macintosh et al (2002) menjelaskan bahwa nilai dominasi yang tinggi pada satu spesies dimungkinkan dapat diindikasikan sebagai lingkungan yang mengalami stres sementara keragaman yang lebih tinggi menunjukkan kondisi stabil dalam ekosistem. Jadi jika dihubungkan dengan hasil penghitungan nilai dominansi dan pernyataan diatas dapat dikatakan bahwa tidak ada spesies yang mendominasi pada tiap stasiun penelian di kawasan hutan mangrove Pantai Bama Taman Nasional Baluran.

c. Faktor Abiaotik

Faktor abiotik yang di lakukan pengukuran pada penelitian di hutan Mangrove Pantai Bama Taman Nasional Baluran meliputi suhu, pH. Dari hasil pengukuran suhu yang di lakukan dari seluruh stasiun di ketahui berkisar antara $30{ }^{\circ} \mathrm{C}-34{ }^{\circ} \mathrm{C}$ adanya perbedaan suhu ini di sebabkan oleh penetrasi cahaya matahari, pasang surut dan adanya naungan oleh tumbuhan mangrove dan apabilah suhu yang melampaui $40{ }^{\circ} \mathrm{C}$ maka akan menyebabkan ketidak seimabangan biota laut. Oleh karna itu Suhu di Hutan Mangrove Pantai Bama Taman Nasional Baluran tergolong baik baik bagi kehidupan Gastropoda Mangrove yang terdapat di Hutan Mangrove Pantai Bama. Menurut Nybakken (1988) mengatakan bahwa suhu di bawah $40{ }^{\circ} \mathrm{C}$ masih tergolong baik bagi kehidupan moluska, akan tetapi jika lebih dari $40{ }^{\circ} \mathrm{C}$ dapat menyebabkan kematian pada semua jenis biota laut. 
Hasil pengukuran derajat keasaman $(\mathrm{pH})$ di hutan mangrove pantai bama taman nasional baluran memiliki nilai rata-rata pada setiap stasiun 1-3 yaitu berkisar 7.7 - 79. Hutabarat dan Evans (1985) menyatakan bahwa pH air normal adalah 7,2 8.1. $\mathrm{pH}$ air yang demikian masih layak untuk semu kebutuhan hidup organisme. Gastropoda umumnya memerlukan $\mathrm{pH}$ antara 6,5 8,5 untuk kelangsungan hidup dan reproduksi. Pada kondisi perairan yang alami , pH berkisar antara 4,0-8,1 (Guifran et $a l, 2007)$. Dengan memiliki nilai $\mathrm{pH}$ rata-rata dari stasiun 1-3 maka dapat di katakan pH normal bagi kehidupan Gastropoda yang berada di pantai bama taman nasional baluran. Menurut Irawan Saputra (2011). Menyatakan pH merupakan faktor yang paling penting untuk mengontrol aktifitas dan distribusi organisme yang hidup dalam suatu perairan. Oleh karna itu Tinggi rendahnya $\mathrm{pH}$ ini merupakan faktor yang sangat penting untuk mengontrol aktifitas dan distribusi organisme yang hidup di dalam perairan. Nilai $\mathrm{pH}$ yang optimum juga karena adanya pengaruh air laut yang secara bersekala masuk ke hutan mangrove pantai bama saat pasang. Berdasarkan hasil penelitian menunjukkan bahwa suhu, $\mathrm{pH}$ dan pasang surut sangatlah berpengaruh dalam terhadap keanekaragaman Gastropoda Mangrove Pantai Bama Taman Nasional Baluran.

Derajat keasaman $(\mathrm{pH})$ tanah pada lokasi penelitian yang ada di pantai bama taman nasional baluran berkisar antara 6.5-5.7 sehingga dapat dikatakan bahwa $\mathrm{pH}$ substrat di lokasi penelitian tergolong baik untuk perkembangan gastropoda. Kemas Ali Hanafiah, (2012) menyatakan teksttur tanah merupakan salah satu faktor yang mempengaruhi penyebarn gastropoda karena berkaitan dengan ketersediaan nutrien dalam sendimen. Substrat pada ketiga stasiun yang ada di pantai bama taman nasional baluran yaitu berupa berlumpur dan pasir berlumpur, dimana substrat berlumpur dan pasir berlumpur ini merupakan habitat yang paling disukai oleh gastropoda. Hal ini di karnakan zat organik lebih banyak yang terdapat disana sehingga daerah tersebut kaya akan nutrien dan ini sangat baik bagi kehidupan gastropoda Ranti Ayunda (2011). 


\section{KESIMPULAN SARAN}

Kesimpulan dari hasil Penelitian tentang Keanekaragaman kelas Gastropodapada Hutan Mangrove Pantai Bama Taman Nasional Baluran yaitu terdapat 16 Famili, 20 Genus, dan 21 Spesies yaitu terdiri dari Spesies Spaerassiminea miniata, Euchelus atratus,Vexillum daedalum,Cassidula aurifelis,Littorina scabra,Littorina saxatilis,Pugilina choclidium,Chicoreus capucinus,Notocypraea angustata,Polinices tumidus,NeritaArticulata,Faunus ater,Cerithidea quoyii,Cerithidea cingulata,Telescopium telescopium,Lambis lambis,Laevistrombus canarium,Conomurex luhuanus,Trochus niloticus,Vasum turbinellus,Nassarius melanoides. Indeks Keanekaragaman Gastropoda pada stasiun 1 nilai indeks keanekaragaman $\mathrm{H}^{\prime}=2.8384$, pada stasiun 2 indeks keanekaragaman $\mathrm{H}^{\prime}=2.8033$ dan sedangkan pada stasiun 3 indeks keanekaragaman yaitu $\mathrm{H}^{\prime}=$. 2.7589dan jika di lihat secara rata-rata tiap stasiun mulai stasiun 1 sampai stasiun 3, memiliki nilai indeks keanekaragaman $\mathrm{H}^{\prime}=2.8002$ yang di kategorikan nilai keanekaragamannya sedang.Indeks dominansi Gastropoda Hutan Mangrove Pantai Bama Taman Nasional Baluran di semua Stasiun yaitu pada stasiun 1 indeks nilai dominansi $\mathrm{C}=0.0653$ Stasiun 2 indeks nilai dominansi $\mathrm{C}=0.0687 \mathrm{dan}$ pada Stasiun 3 indeks nilai dominansi adalah $\mathrm{C}=$. 0.0743. yang di katagorikan nilai dominansi rendah.

\section{SARAN}

Saran yang perlu dilakukan oleh peneliti selanjutnya adalah melakukan penelitian terkait hubungan keanekaragaman dengan keberadaan vegetasi hutan mangrove pantai Bama agar dapat mengetahui seberapa besar peran vegetasi mangrove terhadap keanekaragaman Gastropoda yang berada di Pantai Bama Taman Nasional Baluran.

\section{Reverensi}


Ayunda, R, 2011, Struktur Komunitas Gastropoda pada Ekosistem Mangrove di Gugus Pulau Pari, Kepulauan Seribu, Skripsi, UniversitasIndonesia.

Ardiyansyah, Fuad. 2018. Pola Distribusi dan Komposisi Gastropoda pada Resort Kucur TN Alas Purwo. Jurnal Biologi dan PembelajaranBiologi. 3 (2) 139-151. Budiman, B. 1991. Penelaahan Beberapa Gatra Ekologi Molusca Bakau Indonesia. Disertasi tidak dipublikasikan. Jakarta: Fakultas Pasca sarjana Universitas Indonesia.

Brower., Zar, J.H., and Von Ende, C.N. 1990. Field and Laboratory Methodes for General Ecology. 4rd Ed. McGraw-Hill. United States of America.

Bengen, D.G, Pesoman Teknis Pengelolaan Ekosistem Mangrove. Pusat Kajian Pesisir dan Lautan IPB. Bogor 2004.

Krebs, 1985. Ecological methodology. New York: Harper and Row Publishers.

Katawinata, K. 1979. Status pengetahuan hutan bakau di Indonesia. Prosiding Seminar Ekosistem Hutan Mangrove.Jakarta: MAP LON LIPI.

Kustanti. 2011. Manajemen Hutan Mangrove.

Odum, E.P., 1971, Fundamental of Ecology. W.B. Sounders Company, Philadelphia. Macintosh DJ, Ashton EC, Havanon S. 2002. Mangrove Rehabilitation and Intertidal Biodiversity: A Study In The Ranong Mangrove Ecosystem Thailand. EstuarineCoastal and Shelf Science. 55(3): 331-345.

Nybakken, J.W. 1988 Biologi Laut, Suatu Pendektan Ekologis. PT Gramedia Pustaka. Jakarta.

Ghufran. M. Kordi. H. K., Andi. B. T. 2007. Pengelolaan Kualitas Air Dalam Budidaya Perairan. Penerbit Rineka Cipta. Jakarta.

Irawan Saputra. 2011. Kepadatan Dan Distribusi Gastropoda Di Wilayah Pesisir Pantai Alai Kecamatan Tebing Tinggi Barat Kabupaten Kepulauan Meranti. Skripsi Biologi FKIP Universitas Riau. Pekanbaru.

Hutabarat, S. dan S. M. Evan. 1985. Pengantar Oseanografi Universitas Indonesia, Jakarta. 